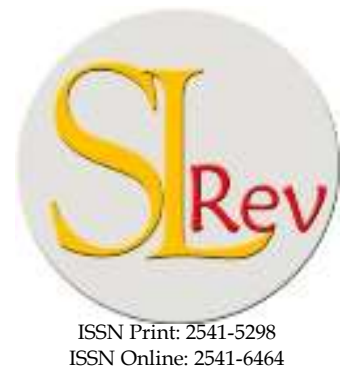

SRIWII

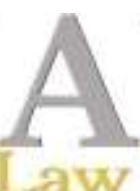

Editorial Office: Faculty of Law, Sriwijaya University Jalan Srijaya Negara, Palembang, South Sumatra 30139, Indonesia. Phone: +62711-580063Fax: +62711-581179

E-mail: sriwijayalawreview@unsri.ac.id| sriwijayalawreview@gmail.com Website: http://journal.fh.unsri.ac.id/index.php/sriwijayalawreview

\title{
The Impact of the Development of Trade Practices on Enforcement of International Environmental Law
}

\author{
Birkah Latif ${ }^{*}$, Syamsuddin Muhammad Noor ${ }^{* *}$, Juajir Sumardi $^{* * *}$ and Irwansyah ${ }^{* * * * *}$
}

\begin{abstract}
The issue of trade and environment is always debatable. Degradation and damaging to the environment surge the countries in making comprehensive and multi-approach planning. This is based on the view that trade should not only count for profit but also carry out calculations and planning for the impacts and conditions when the business is carried out and after completion. The purpose of this paper is to find out whether the environment causes trade not to be carried out and to end economic growth and there is a solution to balance the environment and trade as prevention in both fields through environmental protection legal instruments. The first issue showed that trade that used to be a source of income that is the main target of countries, nevertheless, the unwise planning and also corrupt cases has made the trade become the trigger for environmental damage. This condition caused by a lack of awareness in law enforcement and even various corruption issues causing trade to become a threat, especially for the environment. The second issue arises, which is the mechanism in balancing trade and the environment to preserve the environment and encourage the country's economic growth by optimizing the implementation of environmental protection laws. This paper uses normative legal research methods by collecting data derived from the literature, legislation, articles, and cases that occur within countries. The result shows that more states and stakeholder using more technique on achieving a balance of trade and environment protection, with a pro-environment calculation, it is expected that trade will be carried out in parallel with environmental preservation.
\end{abstract}

Keywords: Economy; Environmental Law; Trade; Valuation.

\section{ARTICLE HISTORY:}

\section{DOI: 10.28946/sIrev.Vol3.Iss2.226.pp137-151}

Received: Jan 4, 2019;

Reviewed: Jun 10, 2019;

Accepted: Jul 27, 2019;

Published: Jul 31, 2019.

\footnotetext{
* Faculty of Law, Hasanuddin University, Makassar, Indonesia. E-mail: birkahlatif@gmail.com

** Faculty of Law, Hasanuddin University, Indonesia. E-mail: smnoorlaw1@gmail.com

*** Faculty of Law, Hasanuddin University, Indonesia.E-mail: juajirsumardi@yahoo.com

**** Faculty of Law, Hasanuddin University, Indonesia. $\quad$ E-mail: irwansyahrawydharma@yahoo.com.
}

\section{INTRODUCTION}

At the time of trade commencement as cross-border in nature, countries have realized that each of them has needs and dependencies to complement one another.

Starting with the model of traditional trades also helped the entire of the trade system, lifting the trend of origin trade itself to a more modern model (from the form of business made of tracing spices which were then induced by colonialism ${ }^{1}$ in a country or

1 Tania El Kallab, The Colonial Impacts on French Trade Patterns, Université Cergy-Pontoise, p1. https://pdfs.semanticscholar.org/9d98/35311d0b8 
region that has richest in natural resources, this stage of the trade then turned into to more modern types of trade and investment starting around the middle ages-16th century.

The dynamic changes in economic conditions, also lead the direction of the change of economic behavior, this can be seen from research by Eileen Power, which states: ${ }^{2}$

"The period after the middle of the fourteenth century was thus one of decline and stagnation, and it brought with it a change in an agrarian organization. Everybody now knows that the second half of the fourteenth and the fifteenth century was an age in which demesne farming was shipwrecked, and lords, instead of cultivating home farms and selling the cash crop themselves, leased them and became transformed into a rentier..."

From the above text, the writer concludes that the trade trends are influenced by conditions in various conditions on the market, including the demand for markets, as well as trends in the trading market. If later trade came out with "a deadlock of demand" occurs, the state as an actor will immediately justify the direction of its economic trade policy.

The United Nations Conference on Trade and Development (UNCTAD) mentioned: ${ }^{3}$

a45e336798b12265eb09c188ca8.pdf, (retrieved: May 1, 2018).

2 Eileen Power, The Wool Trade In English Medieval History, University of London, p26, classhttps://socialsciences.mcmaster.ca/econ/ugc m/3113/power/WoolTrade.pdf, (retrieved: May 1, 2018).

3 Alessandro Nicita and Bolormaa TumurchudurKlok, New And Traditional Trade Flows And The Economic Crisis, UNCTAD: Policy Issues In International Trade And Commodities Study Series No. 49, 2011. https://unctad.org/en/ Docs/itcdtab50_en.pdf, (retrieved: May 2, 2018).
"Many factors determine bilateral trade flows. In addition to supply and demand factors, government policies, trade costs, geography, cultural links, and experience in trade relationships also play an important role as determinants of international trade..."

If we look at the direction of modern international trade (including free trade), it can be said that Adam Smith and David Ricardo gave the initial placement of the theory of free trade. Adam Smith supported modern economists and one of the first and most well-known thinkers who helped free trade. $^{4}$

Their initiation of the theory of free trade can be seen from their work as follows in the 1776 and 1826, where Adam Smith wrote his work entitled Wealth of Nations. Meanwhile, David Ricardo's in 1951 wrote about the Principles of Economics.

Both Smith and Ricardo are in a group of classical where a classical emphasis on productivity and labor costs that differently with the neoclassical view on choosing the portion of the endowment. ${ }^{5}$

The view of comparative economic advantages also being criticized: ${ }^{6}$

"...use economic theory to analyze some of the gains and losses associated with the environmental effects of trade. The theory of comparative advantage tells us that both trading partners gain from trade through

4 Reinhard Schumacher, Adam Smith's theory of absolute advantage and the use of adoxography in the history of economics, Erasmus Journal for Philosophy and Economics, Volume 5, Issue 2, 2012, p54.

5 Stephen S. Golub and Chang-Tai Hsieh, 2000, "Classical Ricardian Theory of Comparative Advantage," Review of International Economics, 8 (2), p1.

Available from: http://www2.econ.iastate.edu/ classes/econ521/orazem/Papers/Golub_hsieh.pdf. (retrieved: December 12, 2018).

6 Jonathan M. Harris, Trade and the Environment, Global Development And Environment Institute, Tufts University, 2004, p2. 
specializing in the goods that they can produce most efficiently. But this basic theory does not consider environmental externalities that may be associated with the production or consumption of goods."

This comparative advantage theory seeks to emphasize the "distinguishing features" or what is referred to as the comparative advantage of a trader (for example if another country can produce high-quality beef cattle, it will be a superior product for it) and able to increased its products to make a profit. This theory directs the recall of trade but does not include the calculation of the negative impact itself on the environment from the production or consumption of goods.

The development of trade has also been rolling very rapidly and also raises a range of issues within it. The issue against the presence of trade its how the trade that enters countries influences the existence of society and in particular the existing environment. J. S. Mill further stated that "to do the balancing act by introducing the notion of "Reciprocal Demand."'7

A few years later Alfred Marshall further advanced the role of demand in terms of the "offer curve" construct, which, according to him, completed the Ricardian trade theory by determining the "terms of trade."

The foundation of the "reciprocal" atmosphere is the primary milestone of trade, where countries have their needs and dependencies. However, on the other hand there is also a tendency towards the risk of trade where the primary orientation is only focused on profit alone.

7 Sunanda Sen. 2010. International Trade Theory and Policy: A Review of the Literature. Levy Economics Institute. p8.
For example, in some cases, it was found that trade carried out in the form of direct investment in capital receiving countries experienced many environmental problems. According to Forest Watch Indonesia records ${ }^{8}$ In the period 2009 2013, Indonesia lost 515.9 thousand hectares of natural forest due to the conversion of forests into oil palm plantations. ${ }^{9}$

Pontus Braunerhjelm cited the report from Environmental Effects of International Trade on considering: ${ }^{10}$

Empirical studies of cross-country data generally find no detrimental effects of trade on some measures of environmental degradation such as local SO2 (sulfur dioxide) air pollution, controlling for income. The evidence does suggest that trade and growth can exacerbate other measures of environmental degradation, however, particularly $\mathrm{CO} 2$ emissions (carbon dioxide)...

Various cases of environmental damage make the countries involved in the trade more careful in putting their trade policies in place.

The concerns about the possibility of more bad impact as a result of trade

8 Fadhil Muhammad Indrapraja, Analisis Terhadap Sertifikasi Minyak Kelapa Sawit Berkelanjutan Sebagai Instrumen Penaatan Hukum Lingkungan, Indonesian Center for Environmental Law (ICEL), Jurnal Hukum lingkungan Indonesia, Vol. 4 Issue 2 / Februari / 2018, p47.

9 Despite contributing positively to the economy, the development of palm oil production also harms the environment and social life. Various investigations have found evidence that shows environmental and social problems caused by the palm oil industry activities.

10 Jeffrey Frankel, Environmental Effects of International Trade, Harvard University- Expert Report Number 31 To Sweden's Globalisation Council, 2009, pI. https://sites.hks.harvard.edu/fs/ jfrankel/Swenvirinlaga31 proofs.pdf. [retrieved: May 3, 2018]. 
development and economy that are not balanced by environmental concerns will stimulate new legal rules on the environment. Environmental principles, such as the principle of sustainability, intergenerational equity, and the polluterpay principle, are the vital instrument for the legal protection of the environment, which will be influenced by various human activities.

Stockholm Declaration on Human and Environment "in 1972 proclaimed 7 (seven) main issues relating to humans and their environment, including:

"...recognition between relationships that cannot separate humans and nature, environmental protection is a major issue for humans and government, much of the environmental damage in developing countries is caused by poverty, increasing population is a major problem in environmental protection."

One interesting theory is the inclusion of the principle of sustainability: ${ }^{11}$

"The concept of sustainability has been an influential part of the lexicon of environmental law since the late 1980s and has been subject to extensive analysis and debate among academics and regulators. In an important new addition to this scholarship, Klaus Bosselmann's The Principle of Sustainability: Transforming Law and Governance is an interesting interdisciplinary exposition of the historical and philosophical foundations of the concept of sustainability and ecological integrity in the context of law and governance."

The debate over trade and the environment that must be combined resulted in long discussions which began formally since 1980. One influential scholar was Klaus Bosselmann's The Principle of

11 Willemien du Plessis, Book review Klaus Bosselmann, "The Principle of Sustainability: Transforming Law and Governance (Ashgate, Aldershot, Hampshire 2008)," Journal of Human Rights and the Environment, Vol. 1 No. 1, March 2010, p121.
Sustainability: Transforming Law and Governance, which sought a multidisciplinary approach, in particular, the influence of law-makers and governance emphasizes the principle of sustainability.

Ten years after the Stockholm Declaration, the UN General Assembly reaffirmed their commitment to the importance of protecting the environment with state leaders through the 1982 World Charter for Nature in one sentence and 'preamble' clearly stated that: ${ }^{12}$

"Mankind is a part of nature and life depends on the uninterrupted functioning of natural systems which ensure the supply of energy and nutrients."

With the various international forums that have made us aware that the issue of the environment relating to the economy and trade has become a concern of the world community.

Because there is a connection between it, a pattern of approach between law and trade is also needed: ${ }^{13}$

"Law needs economics to understand its behavioral consequences, and economics needs a law to understand the underpinnings of markets."

The content of the concept of sustainable development is the main milestone of environmental protection, which is a soft law, which is then transformed by countries in their national policies. This research will deal with environmental protection through legal instruments which hinder economic growth and the balancing of environmental preservation with development of trade.

12 UN General Assembly, World Charter for Nature, A/RES/37/7, 48th plenary meeting, 28 October 1982.

13 Robert Cooter, Law and Economics, 6th edition, Berkeley Law, 2016, p9. 


\section{RESEARCH METHODS}

In finding solutions to the problems above, the author uses normative legal research methods, by collecting data derived from the literature, legislation, articles, and cases that occur within countries.

\section{ANALYSIS AND DISCUSSION Environment}

Maarten Hajer, in his writing "Discourse Coalitions and the Institutionalization of Practice: The Case of Acid Rain in Britain," says that "...An environmental discourse is 'social construct."'14

The definition of environment and development is inseparable from various conditions in the past where environmental issues are still scattered and not yet codified. When environmental issues begin with concerns over the loss of bird voices due to the use of pesticides "in Silent Spring" where the danger of overuse of misuse, the issue of the danger of oil spills that occur from oil tankers in the sea such as Torrey Canyon, protection of wild animals ${ }^{15}$ and also Plant and Animal Protection and Disease Control is an indication for the state to preserve its environment.

The excerpts of Maarten Hajer's views which were originally interpreted were only limited to social concerns by legal experts by looking at the existing conditions and then pouring in the legal formulations and regulations.

Orlando Rey Santos stated that formulation of law is the main part of making the framework on guiding the

14 Brad Jessup and Kim Rubenstein, Environmental Discourses In Public and International Law, Cambridge University Press, 2012, p7.

15 Daud Silalahi, Hukum Lingkungan dalam Sistem Penegakan Hukum Lingkungan Indonesia Hukum Lingkungan Internasional, Alumni, 1992, p142. environmental usage and create the social protection: ${ }^{16}$

These movements can be seen in the increasing presence of environmental regulations, below which are divided into several parts of the environment itself

1. The protection regime of the marine environment consists of several conventions, namely:

a) 1974 Paris Convention

This convention is also commonly called the 1973 Paris Convention for the Prevention of Marine Pollution from Land-Based Source. This convention consists of 29 articles and 2 Annexes that require participating countries to individually or jointly prevent marine pollution from landbased pollutants. This Convention regulates the types of contaminants that are prohibited as well as restrictions, which may be included in the sea.

b) 1976 London Convention

This convention is the first international convention, which considers that the act of polluting the marine environment is an act against the law. Therefore, this convention requires every company that conducts offshore pollution both from the installation or from the ship to assume financial responsibility for the

16 Orlando Rey Santos, Environmental Law as Guarantor of Social Justice, p2, https://law.yale.edu/system/files/area/center/kame 1/sela16_rey_cv_eng.pdf. [retrieved: May 3, 2018]. 
damage suffered by the victim or the victim's country.

c) 1982 Sea Law Convention

This Convention does not explicitly regulate environmental pollution, but generally, it regulates the prevention of sea pollution. According to this convention, each country has sovereign rights ${ }^{17}$ to take natural resources in the sea or on the seabed. In addition, the current convention also requires participating countries to use environmentally conscious technology.

For this reason, countries in the world are required to cooperate in making technology and regulations for protecting the marine environment. ${ }^{18}$

2. Atmospheric Protection:

a) 1985 Vienna Convention

This convention shows the international community's awareness of the threats that will arise to the world's atmosphere. This Convention does not contain standards that must be met to limit ozone-depleting substances. Even so, it can be used as a foundation for working together to

17 Some constitutional law experts argue that sovereignty is absolute and cannot be negotiated. Nurhidayatuloh and Febrian, 2019 "Asean and European Human Rights Mechanisms, What Should Be Improved?" Padjajaran Jurnal Ilmu Hukum (Journal of Law), 6 (1), p153.

18 According to this convention, the state has sovereign rights over its biological resources, but the state also has an obligation to protect and preserve biological resources contained in its territory. The considerations for ratifying this convention include that the biodiversity in the world in the world plays an essential role in the continuation of the evolutionary process and the maintenance of ecosystems and systems of life for the biosphere. protect the ozone layer, which has proven to be running low.

b) 1992 Convention on Climate Change This convention is intended to regulate the use of greenhouse gases, which are the cause of global warming and global climate change. This Convention was followed up with "The Kyoto Protocol," which included quantitative reduction norms for greenhouse gas emissions along with their action plans.

3. Nature conservation:

a) CITES 1973

The aim of this Convention on International Trade in Endangered Species of Wild Fauna and Flora is to protect biodiversity through the trade of certain species internationally, which results in the preservation of these species being threatened.

b) Convention on Biological Diversity 1992

This convention has three main objectives, namely, conserving biodiversity, utilizing biodiversity sustainably, and ensuring equitable sharing of benefits from the use of genetic resources. Biodiversity protection, both ex-situ and in-situ and equal sharing between fellow member countries

4. Convention on Hazardous Toxic Material (HTM)

a) Basel Convention concerning export and import of HTM waste (transboundary of hazardous waste) and its management, 
b) The Rotterdam Convention on information on the export and import of dangerous and toxic chemicals,

c) The Stockholm Convention on Persistent Organic Pollutants which are forbidden to use is limited to use.

These three conventions regulate the prohibition of trade and the transfer of HTM waste from a member country to another member country.

With the series of environmental regulations above, it can be seen that studies of trade and the environment are closely related. It cannot be denied that both in the aspect of the operation of the trade there has been an environmental dimension that can and or has felt its effects. Attention to environmental issues and trade is vital in legal review, the cover of protection of economic on trade on the scope of the environment through marine environment, atmospheric protection, nature conservation, Hazardous Toxic Material (HTM) are the pillars of regulations. The enforcing of economic-based environmental laws is also included in multilateral international arrangements both (through the World Trade Organization) various legal provisions with specific issues have also been made and even on the national level of countries arrangements. Those legal arrangements are very dynamic following the form and pattern of the existing economic trade relations.

\section{Environment and Trade: An Economic Approach}

Different conditions are also increasingly visible when the environment is associated with the trading area. International institutions and or organizations also support the efforts of the state to examine more proenvironment trade issues.

\section{World Trade Organization (WTO) mentioned: ${ }^{19}$

\begin{abstract}
"The link between trade and environmental protection, consisting of both the impact of environmental policies on trade, as well as the impact of trade on the environment, was recognized as early as 1970.”
\end{abstract}

The peak of attention to environmental issues was accompanied by the presence of the Stockholm Conference on the Human Environment conference in 1972. The concerns become significant consideration each time the countries selecting the way of their trade: ${ }^{20}$

"The trade community is concerned about the trade impacts of measures taken in the name of the environment. These measures include both domestic environmental regulations, which can have side effects on trade, and explicit trade restrictions taken in the name of environmental concerns. Whether intentionally or not, some such measures have the potential to restrict trade more than is necessary to achieve environmental goals. In some cases, the disruption of trade also might be out of proportion to the environmental benefit."

Meanwhile, in terms of trade, especially economics, there were also pros and cons to the patron of trade developments which were initially considered to be old models. Examples of old trading models when the comparative cost era applies ${ }^{21}$ And the HOS

19 the World Trade Organization. Early years: emerging environment debate in GATT/WTO.Weblog. [Online] Available from: https://www.wto.org/ english/tratop_e/envir_e/hist1_e.html

20 U.S. Office of Technology Assessment(1992) Trade and the Environment: Conflicts and opportunities, Report no. OTA-BP-ITE-94. Weblog. [Online]Available from:http://ciesin.org/ docs/008-067/chpt1.html. (retrieved: December 15, 2018)

21 Era of Smith dan Ricardo. 
models ${ }^{22}$ which is still felt to be less precise in describing the direction of the free trade. After that, the era of "overlapping demand" also emerged, which stated the correlation above: ${ }^{23}$

"To produce and trade, representative demand in the respective countries needs to have an overlapping zone in terms of the range of goods that are produced and consumed in common. In terms of the above interpretation of trade, it is demand and not supply that comes to the center stage as an explanation of trade."

The era of "overlapping demand" was also later abandoned by economists and other economic actors, which ended the age of the old model of free trade. The era and time-level of the free trade then entered a new milestone with the start of "the New Trade Theory (NTT)" with a note: ${ }^{24}$

"A major point raised in these modifications included the impact of increasing returns to scale on the pattern as well as on the mutual benefits from international trade."

\section{Moreover, the NTT also elaborate: ${ }^{25}$}

"Strategic trade models also involve consideration of the policy instruments that governments are allowed to deploy and the sequencing of decision-making."

22 The era of Heckscher-Ohlin-Samuelson which contains: the doctrine of free trade where the state has a contribution (endowment), and the state has equal access to technology (different from the Ricardian theory). In general, world prices are regulated at the level of the boundaries of (for example) two countries. In the HOS, the theory of free trade includes real protection and purchase. What was agreed upon with HOS was the existence of "rare factors" from countries given by other countries. An example is the component of workers who will differ in salary. If they compare they work in the USA and in other countries.

23 Sunanda Sen. Note 7. p5.

24 Sunanda Sen. Note 7. p6.

25 Sonali Deraniyagala and Ben Fine. New Trade Theory Versus Old Trade Policy: A Continuing Enigma. Available from:https://www.soas.ac.uk/ economics/research/workingpapers/file28872.pdf. (retrieved: December 11, 2018).
The New Trade Theory seeks to get out of the old model with an emphasis on: ${ }^{26}$

"...conclude that the welfare effect of the variegated consumption basket outweighs the losses, if any, from the movement from autarky to free trade. These losses may affect the small producers who are unable to reap the economies of scale, which permit them to cover fixed cost."

Krugman ${ }^{27}$ also added that the press point of New Trade Theory is to be able to provide potential gain to all actors (countries) in trade by gaining "profits" from trade globally.

Supporters of New Trade Theory in the 1970s side by side with the issue of environmental protection (the international conference on the environment) began to be raised. Although this New Trade Theory is as unsuccessful as the old model of free trade because it is still considered unfair, it then ignites the emergence of the Marxist era which states that: ${ }^{28}$

"Trade had a major role in the process, providing access to markets hitherto unexploited. The emphasis on trade continued in the debates that came up in related themes on capitalism..."

That the tendency for countries that have been colonized will be challenging to adjust to the free trade arena because they become a market share and there is "independence" that holds them back. This thought was pioneered by Latin American thinkers.

This era did not last long because then it could be broken with the real consensus that it turned out that they (including developing countries and incidentally were former colonies) were mistaken in translating autarky and even stagnating in their

\footnotetext{
26 Sunanda Sen. Note 7. p8.

27 Sunanda Sen. Note 7. p8.

28 Sunanda Sen. Note 7. p12.
} 
economies. Facts about developing countries that: ${ }^{29}$

"...the experience of the newly industrialized economies of East Asia, namely Hong Kong, Singapore, Taiwan and South Korea, during the 1970s and 1980s showed that their success had been the result of emphasizing trade with the advanced industrial countries..."

The Marxist era was later abandoned and entered Neoclassical CounterRevolution Models). There are 3 (three) differentiators in the determination of the Counter-Revolutionary Neoclassical Model (Neoclassical Counter-Revolution Models), namely ${ }^{30}$ the free market, the new political economy approach, and the market-friendly method.

Which then also experienced improvements to the formation of free trade at this time. What becomes the focus after this free trade is the entry of the concept of new growth theory with the theory of coordination failure that seeks to improve the position of the free trade and its previous development cycle.

Correlation of the environment was also carried out not only at environmental conferences but also received responses from existing international organizations, including international organizations engaged in trade. World Trade Organization (WTO) $)^{31}$ also contributed to the preparation of the Stockholm conference with: ${ }^{32}$

29 Dang G., Sui Pheng L., Theories of Economic Development. In: Infrastructure Investments in Developing Economies, Springer, Singapore, 2015, p18.

30 Dang G., Sui Pheng L., Note 28, p19.

31 At that time was called as GATT.

32 GATT (1971), Trade and the environment in the GATT / WTO: 'Industrial Pollution Control and International Trade,' GATT Studies in International Trade, No. 1. GATT: Geneva, UN (1971) Development and Environment, Report and Working Papers of a Panel of Experts
"The Secretariat of the GATT was requested to contribute. On the Secretariat's responsibility, a study entitled "Industrial Pollution Control and International Trade" was prepared."

The GATT Secretariat then reports on the links between the environment and trade-related to industrial pollution. The following year the parties from the GATT then directed their members to examine the environmental implications of international trade. In this year a group was formed to measure the environment and international trade called Environmental Measures and International Trade (EMIT group). ${ }^{33}$

\begin{tabular}{ll}
\hline $\begin{array}{c}\text { N Year } \\
\text { o }\end{array}$ & \multicolumn{1}{c}{ Results } \\
\hline $1.1973-$ & $\begin{array}{l}\text { Tokyo Round of trade negotiations: } \\
\text { a) the degree to which environmental } \\
\text { measures }\end{array}$ \\
& $\begin{array}{l}\text { b) } \\
\text { regulations and standards could form } \\
\text { obstacles to trade. }\end{array}$ \\
& The Tokyo Round Agreement on \\
Technical Barriers to Trade (TBT), also \\
known as the "Standards Code" for non- \\
discrimination in the preparation, \\
adoption, and application of technical \\
regulations and standards, and for them \\
to be transparent.
\end{tabular}

Convened by the Secretary-General of the United Nations Conference on the Human Environment, Founex, Switzerland, June 4-12, 1971.

33 World Trade Organization stated:

"In November 1971, the GATT Council of Representatives agreed to set up a Group on Environmental Measures and International Trade (also known as the "EMIT" group), which would be open to all GATT members (i.e., GATT signatories). However, the decision also said the group would only convene at the request of GATT members. Therefore, it was not until 1991 when the members of the European Free Trade Association asked for the EMIT Group to be convened. (EFTA, at the time included Austria, Finland, Iceland, Liechtenstein, Norway, Sweden, and Switzerland)," See World Trade Organization. Note 8. 


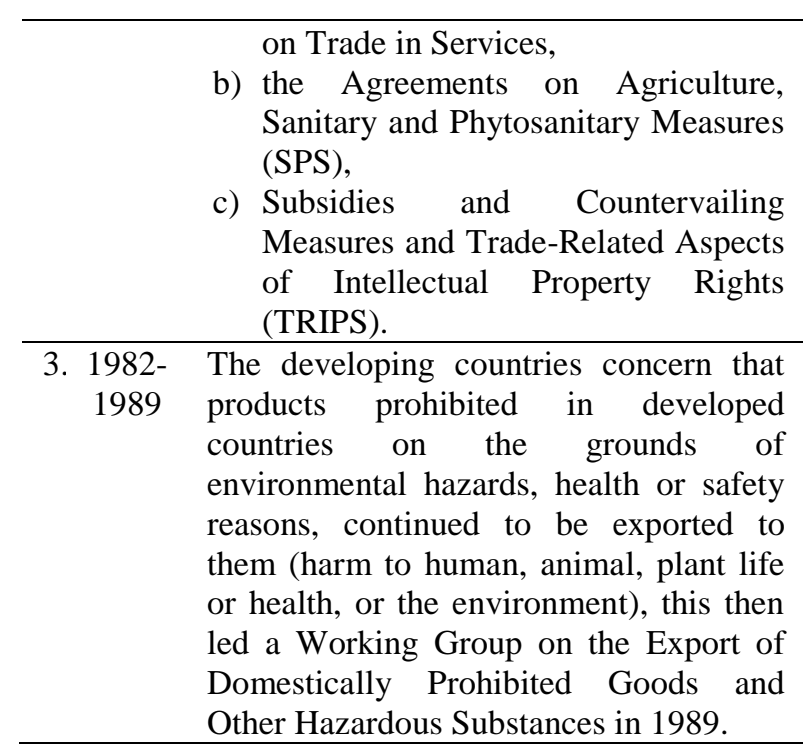

By looking at the trajectory of time and various issues related to the environment, it is inevitable that trade must indeed be directed and protective of environmental damage that can be caused by it.

\section{Trade Practices on Enforcement of Environmental Protection Laws}

With various movements and cases that caused anxiety over the issue of environmental damage, in 1987 the World Commission on Environment and Development provided the concept of sustainable development as a concept used in resolving conflicts between environment and development (including trade in it):

"Sustainable development is a development which meets the needs of the present without compromising the ability of future generations to meet their own needs."

Jonathan Haris concluded that there are three (3) main issues of sustainable development, namely: ${ }^{34}$

1. Economic: An economically sustainable system must be able to produce goods and services continuingly, to maintain manageable levels of government and

34 Jonathan M. Harris, Sustainability and Sustainable Development, International Society for Ecological Economics, 2003, p1. external debt, and to avoid extreme sectoral imbalances which damage agricultural or industrial production.

2. Environmental: An environmentally sustainable system must maintain a stable resource base, avoiding over-exploitation of renewable resource systems or environmental sink functions, and depleting non- renewable resources only to the extent that investment is made inadequate substitutes. This includes maintenance of biodiversity, atmospheric stability, and other ecosystem functions not ordinarily classed as economic resources.

3. Social: A socially sustainable system must achieve fairness in distribution and opportunity, adequate provision of social services, including health and education, gender equity, and political accountability and participation.

The question that then arises is how to ensure that actors from development can think of the formulation in its implementation? What is the standard for balancing the pattern of management from the government for the economic dimension? How to measure and prepare a balance between natural resources so that there is no over-exploitation? How to seek equal access and opportunities in social blows? These questions then lead various stakeholders to approaches that are multiaspect and multi-approach.

By seeing to the sequence of developments from the economic and trade era above, it was found that the approach that interacts with other components related to the economy/development/trade will considerably have implications for the environment. For this reason, when Brutland's concept of sustainable 
development was announced, it was considered to be very related to changes in views that had been based on economic growth based on using natural resources towards ecological friendly optimization, to avoid misuse or overexploitation. A robust sustainability approach is based on the idea that substitutability between natural and manufactured capital is limited.

Furthermore, the implementation of the concept of sustainable development was then carried out by the United Nations (UN) to all its members in 2015. The UN made the 2030 Agenda for Sustainable Development (SDGs) which contained shared blueprints for peace and prosperity for people and the planet, now and into the future.

For the notes, the High-Level Political Forum (HLPF) is the organ of existence and being as the home for SDGs: ${ }^{35}$
"that a robust review mechanism is needed to fulfill this role; each time an SDG target is decided, the need to measure progress must be remembered; transparency and accountability for implementation are critical, and should apply to both developing and developed countries, and the review should be linked with the Development Cooperation Forum (DCF) to avoid duplication."

SDGs include 17 goals, namely: 1) Ending all forms of poverty anywhere; 2) End hunger, achieve food security and improve nutrition, and encourage sustainable agriculture; 3) Ensure a healthy life and promote prosperity for all people of all ages; 4) Ensure inclusive and equitable education

\footnotetext{
35 International Institute for Sustainable Development (2014) Briefing Note On The Workshop On Making The High-Level Political Forum On Sustainable Development Work: How To Build An Effective "Review Mechanism." HLPF Bulletin. [Online] p1. Available from: http://enb.iisd.org/hlpf/hlpfsdw/html/crsvol221 nu m1e.html
}

and encourage lifelong learning opportunities for everyone; 5) Ensure gender equality and empower all women and girls; 6) Ensure the availability and management of water and sustainable sanitation for everyone; 7) Ensure affordable, guaranteed, sustainable and modern energy access for everyone; 8) Encourage continuous, inclusive and sustainable economic growth, as well as full and productive employment opportunities and decent work for everyone; 9) Building resilient infrastructure, encouraging inclusive and sustainable industrialization and fostering innovation; 10) Reducing disparities within and between countries; 11) Making cities and human settlements inclusive, safe, resilient and sustainable; 12) Ensure sustainable production and consumption patterns; 13) Take immediate action to combat climate change $^{36}$ and its effects; 14) Conserve and use oceans, oceans and marine resources in a sustainable manner for sustainable development; 15) Protect, renew, and encourage the use of sustainable land ecosystems, manage forests sustainably, fight desertification, stop and restore land degradation, and stop loss of biodiversity; 16) Encouraging a peaceful and inclusive society for sustainable development, providing access to justice for all people, and building effective, accountable and inclusive institutions at all levels; 17) Strengthening implementation tools (means of implementation) and revitalizing global partnerships for sustainable development.

36 Climate change in Indonesia has impacted on the annual rainfall whichalready down by 2 to 3 per cent, and the seasons are changing. Achmad Romsan, et al., 2017, "Climate Change and Community Environmental Conflicts: Are They Correlated?," Sriwijaya Law Review, 1 (1), p56. 
SDGs are directed to developed and developing countries to cooperate in carrying out these goal actions.

Apart from that starting also developed the simplest economic method is the use of: $:^{37}$

"The benefit-cost analysis as the basis for making decisions about water resources investments came into its own more than 50 years ago. However, since the 1950s when the techniques of conventional benefit-cost analysis were being developed and refined, there have been significant changes in the nature of the problems being dealt with and the analytical tools that have become available."

The valuation of economic values towards this environment then developed over: ${ }^{38}$

"The economic values of the service flows from a resource-environmental system can be viewed as the product of three sets of functional relationships."

Tim Everett mentions the contribution of the natural environment plays an important role in supporting economic activity: ${ }^{39}$

"directly, by providing resources and raw materials such as water, timber, and minerals that are required as inputs for the production of goods and services; and indirectly, through services provided by ecosystems including carbon sequestration, water purification, managing flood risks, and nutrient cycling."

As an extension of the indication of economic risk, the calculation is based on:

1. The first relates some measure of environmental or resource quality to the human interventions that affect it. There

37 A. Myrick Freeman III, et al., The Measurement of Environmental and Resource Values Theory and Methods, Third Edition, RFF Press, 2014, p10.

38 A. Myrick Freeman III, Note 35. p28.

39 Tim Everett et al., 2010, "Economic Growth and the Environment," Defra Evidence and Analysis Series, $\mathrm{p} 7$. are two types of interventions for humans as actors, namely: ${ }^{40}$

a) the unregulated activities of the market economy (for example, the commercial exploitation of a fishery or the discharge of pollutants into the air), and these will be left implicit in the relationships presented here.

b) The government actions; taken to prevent or ameliorate the adverse impacts of unregulated market activities, or to protect or enhance the value of market and nonmarket services provided by the environment.

2. The second set of functional relationships involves the human uses of the environment or resource and their dependence on a qualitative or quantitative measure of some environmental or resource attribute.

3. The third set of functional relationships gives the economic value of the uses of the environment. This is related to value judgments society has for economic welfare purposes.

The benefit-cost analysis as the basis for making decisions about water resources investments came into its own more than 50 years ago. However, since the 1950s when the techniques of conventional benefit-cost analysis were being developed and refined, there have been significant changes in the nature of the problems being dealt with and the analytical tools that have become available.

From sustainable development view using the goals of the SDGs, especially in mean implementation, countries should begin to include valuations on commercial use of the environment that will influence

40 Tim Everett. Note 37. p28. 
and give consideration for countries who believed that encouragement of development with the aim of benefit had been given opposite results. Negligence in management and planning of natural resource management will ultimately lead to scarcity of natural resources and increase the length of cases of environmental degradation.

\section{CONCLUSION}

On the development side of countries tend to achieve more economic pressure from other countries, these, making countries to push more activities on economic activities, in terms of trade as one of their economic tools. But, then the unwise of handling and preparing of policy boost great disaster to the prominent aspect of living, environment as the part.

All of the stakeholders facing these situations agree to make structural and effective mechanism for it. The multidimensional approach is also useful to maintain the prediction and valuation. The using of economic approach with the mechanism of prediction can describe and calculate the real result of development through trade.

The stimulant calculation methods such as the benefit-cost analysis or valuation of economic values can be seen as the way out in making the trade more supportive and prioritizing the environment. One concept that unites the multidisciplinary relationship between trade and the environment can be seen in the principle of sustainability. Incorporating sustainable principles into policies and regulations in countries will be appropriate in implementing trade and environmental practices.

\section{REFERENCES \\ Books:}

Cooter Robert. Law and Economics. Berkeley Law. 6th edition. 2016.

Freeman, A. Myrick., Joseph A. Herriges, and Catherine L. Kling. 2014.The Measurement of Environmental and Resource Values Theory and Methods. Third Edition. RFF Press.

G. Dang., Pheng L., Theories of Economic Development In Infrastructure Investments in Developing Economies. Springer. 2015.

Harris, Jonathan M. 2003. Sustainability and Sustainable Development. International Society for Ecological Economics.

.2004. Trade and the Environment. Tufts University:Global Development and Environment Institute.

Jessup, Brad and Kim Rubenstein. 2012.Environmental Discourses In Public and International Law. Cambridge University Press.

Sen, Sunanda. 2010. International Trade Theory and Policy: A Review of the Literature. Levy Economics Institute.

Silalahi, Daud. 1992. Hukum Lingkungan Dalam Sistem Penegakan Hukum Lingkungan Indonesia Hukum Lingkungan Internasional. Alumni.

UN General Assembly, World Charter for Nature, A/RES/37/7, 48th plenary meeting, 28 October 1982.

\section{Journals:}

Everett, Tim., Mallika Ishwaran, Gian Paolo Ansaloni, and Alex Rubin. 2010. "Economic Growth and the Environment." Defra Evidence and Analysis Series. 
Fadhil Muhammad Indrapraja, Analisis Terhadap Sertifikasi Minyak Kelapa Sawit Berkelanjutan Sebagai Instrumen Penaatan Hukum Lingkungan, Indonesian Center for Environmental Law (ICEL), Jurnal Hukum lingkungan Indonesia, Vol. 4 Issue 2 / Februari / 2018.

Golub, Stephen S., and Chang-Tai Hsieh. 2000."Classical Ricardian Theory of Comparative Advantage". Review of International Economics. 8 (2).

Nurhidayatuloh and Febrian. 2019. “Asean and European Human Rights Mechanisms, What Should Be Improved?" Padjajaran Jurnal Ilmu Hukum (Journal of Law). 6 (1).

Romsan, Achmad, Farida Ali, Akhmad Idris, Adrian Nugraha, Nurhidayatuloh, Suzanna Mohamed Isa. 2017. "Climate Change and Community Environmental Conflicts: Are They Correlated?." Sriwijaya Law Review. 1 (1).

Schumacher, Reinhard. 2012. Adam Smith's theory of absolute advantage and the use of adoxography in the history of economics. Erasmus Journal for Philosophy and Economics, 5 (2).

Willemien du Plessis, Book review Klaus Bosselmann, The Principle of Sustainability: Transforming Law and Governance (Ashgate, Aldershot, Hampshire 2008). 2010. Journal of Human Rights and the Environment. 1 (1).

\section{World wide web:}

Alessandro Nicita and Bolormaa Tumurchudur-Klok. New And Traditional Trade Flows And The Economic Crisis. UNCTAD: Policy Issues In International Trade And Commodities Study Series No. 49. 2011. https://unctad.org/en/Docs/ itcdtab50_en.pdf, (retrieved: May 2, 2018).
Eileen Power. The Wool Trade In English Medieval History. The University of London.

classhttps://socialsciences.mcmaster.ca/econ /ugcm/3113/power/WoolTrade.pdf, (retrieved: May 1, 2018).

International Institute for Sustainable Development (IISD). 2014.Briefing Note On The Workshop On Making The High-Level Political Forum On Sustainable Development Work: How To Build An Effective "Review Mechanism."HLPF Bulletin. Available from: http://enb.iisd.org/ hlpf/hlpfsdw/html/crsvol221 numle.html

Jeffrey Frankel, Environmental Effects of International Trade, Harvard UniversityExpert Report Number 31 To Sweden's Globalisation Council. 2009. https://sites.hks.harvard.edu/fs/jfrankel/Swe nvirinlaga31proofs.pdf. [retrieved: May 3, 2018].

Orlando Rey Santos, Environmental Law as Guarantor of Social Justice, p2, https://law.yale.edu/system/files/area/center/ kamel/sela16_rey_cv_eng.pdf. [retrieved: May 3, 2018].

Sonali Deraniyagala and Ben Fine.New Trade Theory Versus Old Trade Policy: A Continuing Enigma. Available from: https://www.soas.ac.uk/economics/research/ workingpapers/file28872.pdf. [retrieved: December 11, 2018].

Tania El Kallab. The Colonial Impacts on French Trade Patterns, Université CergyPontoise.

https://pdfs.semanticscholar.org/9d98/35311 d0b8a45e336798b12265eb09c188ca8.pdf. [retrieved: May 1, 2018]. 
U.S. Office of Technology Assessment. 1992. Trade and the Environment: Conflicts and opportunities, Report no. OTA-BP-ITE94. from:http://ciesin.org/docs/008-067/ chpt1.html. [retrieved: December 15, 2018].
World Trade Organization.Early years: emerging environment debate in GATT/WTO. Available from: https://www.wto.org/english/tratop_e/envir_ e/hist1_e.html. 